\title{
Isolation of 10-O-Acyl Iridoid Glucosides from a Philippine Medicinal Plant, Oldenlandia corymbosa L. (Rubiaceae)
}

\author{
Hideaki Otsuka, ${ }^{*, a}$ Kayoko Yoshimura,${ }^{a}$ Kazuo Yamasaki ${ }^{a}$ and Magdalena C. Cantoria ${ }^{b}$ \\ Institute of Pharmaceutical Sciences, Hiroshima University School of Medicine, ${ }^{a}$ 1-2-3 Kasumi, Minami-ku, Hiroshima 734, Japan, Faculty of Pharmaceutical \\ Sciences, University of the Philippines at Manila, ${ }^{b}$ Padre Fauna St., Ermita, Manila, Philippines. Received February 18,1991
}

From the aerial parts of Oldenlandia corymbosa, nine iridoid glucoside derivatives were isolated. On spectroscopic investigation, five known compounds were identified, that is, deacetyl asperuloside, asperuloside, asperulosidic acid, deacetyl asperulosidic acid and scandoside methyl ester. The structures of four new compounds were determined to be acylated derivatives of the known compounds, that is, 10- $O$-benzoyl deacetyl asperulosidic acid methyl ester, and 10-O-benzoyl, 10-O-p-hydroxybenzoyl, and 10-O-p-trans, cis-coumaroyl scandoside methyl esters.

Keywords Oldenlandia corymbosa; Hedyotis corymbosa; Rubiaceae; iridoid; asperuloside; scandoside methyl ester; 10- $O$-benzoyl deacetyl asperulosidic acid methyl ester; 10-O-acyl scandoside methyl ester

The constituents of Hedyotis corymbosa LAM. (syn. Oldenlandia corymbosa L., 水線草, Rubiaceae), which was imported from China, have been investigated by Takagi et $a l$., and the isolation of six iridoid glucosides was reported. ${ }^{1)}$ The same group isolated some 6- $O$-acyl scandoside methyl esters from a related plant, Hedyotis diffusa WiLlD. (白花蛇舌草) which was also imported from China through a Hong Kong market. ${ }^{2)}$ These two plants are now used in Chinese medicine as anti-tumor drugs. During further studies on Philippine medicinal plants, ${ }^{3,4)}$ we investigated the constituents of $O$. corymbosa harvested in the Philippines. The whole plant, as a decoction, is used as a febrifuge and a stomachic, and the juice is applied for the burning sensation in the palms of the hands and soles of the feet caused by fever. ${ }^{5)}$ Of the nine iridoid glucosides isolated, four are new compounds. In this paper, determination of the structure of these compounds is described.

\section{Results and Discussion}

The aerial part of $O$. corymbosa was extracted with $\mathrm{MeOH}$. The $\mathrm{MeOH}$ extract was separated by means of a combination of highly porous synthetic resin, Diaion HP-20, silica gel column chromatography, droplet counter-current chromatography (DCCC) and preparative high performance liquid chromatography (HPLC). The isolation and
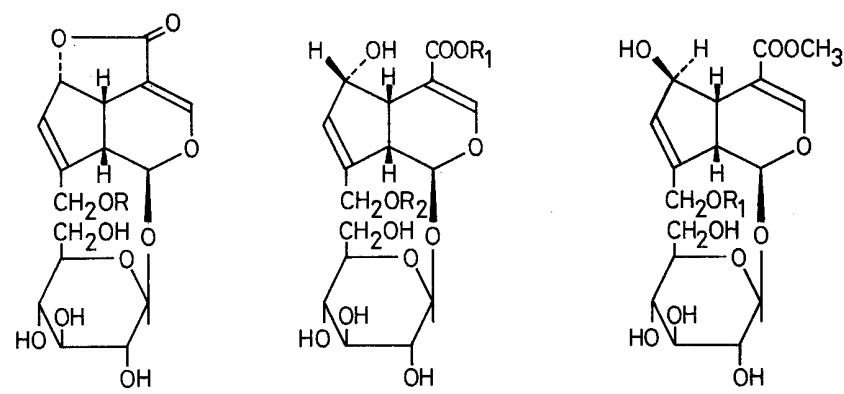

1: $\mathrm{R}=\mathrm{H}$

$2: \mathrm{R}=\mathrm{CH}_{3} \mathrm{CO}^{-}$

$$
3: \mathrm{R}_{1}=\mathrm{H} ; \mathrm{R}_{2}=\mathrm{CH}_{3} \mathrm{CO}-
$$

4: $\mathrm{R}_{1}=\mathrm{R}_{2}=\mathrm{H}$

4a: $\mathrm{R}_{1}=\mathrm{CH}_{3} ; \mathrm{R}_{2}=\mathrm{H}$<smiles>O=C(NC(=O)c1ccccc1)c1ccccc1</smiles>

$5: \mathrm{R}_{1}=\mathrm{CH}_{3} ; \mathrm{R}_{2}=\mathrm{Bz}$

$6: \mathrm{R}_{1}=\mathrm{H}$

$7: \mathrm{R}_{1}=\mathrm{Bz}$

$8: \mathrm{R}_{1}=\mathrm{BzOH}$

9: $\mathrm{R}_{1}=\mathrm{Cou}$

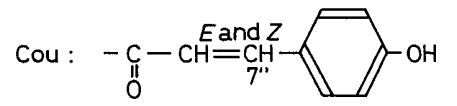

purification procedures are described in detail in the Experimental section.

From the spectroscopic data, compounds 1, 2 and $\mathbf{3}$ were identified as deacetyl asperuloside, asperuloside and asperulosidic acid, respectively. Compound $\mathbf{4}$ was characterized as its methyl ester (4a) ${ }^{6)}$ Since the structure of $\mathbf{4 a}$ was determined to be deacetyl asperulosidic acid methyl ester, the parent compound is the free acid of $\mathbf{4 a}$, namely, deacetyl asperulosidic acid.

Compound 5 was obtained as an amorphous powder, whose elemental composition was determined to be $\mathrm{C}_{24} \mathrm{H}_{28} \mathrm{O}_{12}$ by high resolution (HR)-fast atom bombardment-mass spectrometry (FAB-MS), a cluster ion peak being observed at $m / z 531.1494[\mathrm{M}+\mathrm{Na}]^{+}$on the addition of NaI. Its ultraviolet (UV) spectrum showed maximum absorption at $231 \mathrm{~nm}$ for an aromatic ring, conjugated with a ketone function, and its infrared (IR) spectrum showed the presence of a conjugated ester $\left(1710\right.$ and $\left.1635 \mathrm{~cm}^{-1}\right)$. Its ${ }^{13} \mathrm{C}$-nuclear magnetic resonance (carbon-13 NMR)

TABLE I. ${ }^{13} \mathrm{C}-\mathrm{NMR}$ Data for Compounds $\mathbf{4 a} \rightarrow \mathbf{9}\left(\mathrm{CD}_{3} \mathrm{OD}, 100 \mathrm{MHz}\right)$

\begin{tabular}{|c|c|c|c|c|c|c|c|}
\hline \multirow{2}{*}{$\begin{array}{l}\text { Carbon } \\
\text { number }\end{array}$} & \multirow{2}{*}{$4 a$} & \multirow{2}{*}{5} & \multirow{2}{*}{6} & \multirow{2}{*}{7} & \multirow{2}{*}{8} & \multicolumn{2}{|c|}{9} \\
\hline & & & & & & trans & $c i s$ \\
\hline 1 & 101.6 & 101.4 & 98.7 & 98.5 & 98.5 & 98.52 & 98.58 \\
\hline 3 & 155.4 & 155.4 & 153.9 & 154.0 & 154.0 & 153.99 & 153.99 \\
\hline 4 & 108.3 & 108.2 & 110.9 & 110.7 & 110.7 & 110.65 & 110.65 \\
\hline 5 & 42.7 & 42.5 & 45.8 & 45.6 & 45.6 & 45.63 & 45.70 \\
\hline 6 & 75.4 & 75.4 & 82.5 & 82.3 & 82.5 & 82.34 & 82.34 \\
\hline 7 & 129.9 & 132.0 & 130.4 & 132.9 & 132.6 & 132.59 & 132.80 \\
\hline 8 & 151.5 & 146.0 & 147.5 & 142.1 & 142.4 & 142.30 & 142.08 \\
\hline 9 & 45.9 & 46.5 & 47.3 & 47.8 & 47.8 & 47.64 & 47.58 \\
\hline 10 & 61.7 & 64.3 & 61.1 & 63.7 & 63.7 & 63.00 & 63.00 \\
\hline 11 & 169.5 & 170.3 & 170.3 & 170.3 & 170.3 & 170.29 & 170.29 \\
\hline -COOMe & 51.9 & 52.1 & 52.1 & 52.1 & 52.1 & 52.14 & 52.14 \\
\hline $1^{\prime}$ & 100.5 & 100.8 & 100.5 & 100.6 & 100.6 & 100.53 & 100.53 \\
\hline $2^{\prime}$ & 75.0 & 75.0 & 74.9 & 74.8 & 74.8 & 74.80 & 74.80 \\
\hline $3^{\prime}$ & 78.5 & 78.6 & 78.4 & 78.5 & 78.5 & 78.45 & 78.47 \\
\hline $4^{\prime}$ & 71.6 & 71.6 & 71.6 & 71.5 & 71.5 & 71.48 & 71.54 \\
\hline $5^{\prime}$ & 77.8 & 77.9 & 78.0 & 78.0 & 78.0 & 77.95 & 77.95 \\
\hline $6^{\prime}$ & 62.8 & 63.0 & 62.9 & 62.8 & 62.8 & 62.82 & 62.82 \\
\hline $1^{\prime \prime}$ & & 131.3 & & 131.3 & 122.0 & 127.13 & 127.61 \\
\hline $2^{\prime \prime}, 6^{\prime \prime}$ & & 130.7 & & 130.7 & 133.0 & 131.32 & 133.75 \\
\hline $3^{\prime \prime}, 5^{\prime \prime}$ & & 129.7 & & 129.7 & 116.3 & 116.89 & 115.96 \\
\hline $4^{\prime \prime}$ & & 134.4 & & 134.5 & 163.8 & 161.43 & 161.18 \\
\hline $7^{\prime \prime}$ & & 167.7 & & 167.7 & 167.8 & 147.10 & 145.71 \\
\hline $8^{\prime \prime}$ & & & & & & 116.22 & 114.80 \\
\hline $9^{\prime \prime}$ & & & & & & 168.85 & 167.86 \\
\hline
\end{tabular}


TABLE II. ${ }^{1} \mathrm{H}-\mathrm{NMR}$ Data for Compounds $\mathbf{4 a}-\mathbf{9}\left(\mathrm{CD}_{3} \mathrm{OD}, 400 \mathrm{MHz}\right)$

\begin{tabular}{|c|c|c|c|c|c|c|c|}
\hline \multirow{2}{*}{$\begin{array}{c}\text { Proton(s) } \\
\text { at }\end{array}$} & \multirow{2}{*}{$4 a$} & \multirow{2}{*}{5} & \multirow{2}{*}{6} & \multirow{2}{*}{7} & \multirow{2}{*}{8} & \multicolumn{2}{|c|}{9} \\
\hline & & & & & & & \\
\hline 1 & $5.055(\mathrm{~d}, 8)$ & $5.122(d, 9)$ & $5.190(\mathrm{~d}, 7)$ & $5.268(\mathrm{~d}, 7)$ & $5.257(\mathrm{~d}, 7)$ & $5.216(\mathrm{~d}, 7)$ & $5.179(\mathrm{~d}, 7)$ \\
\hline 3 & $7.651(\mathrm{~d}, 2)$ & $7.669(\mathrm{~d}, 2)$ & $7.507(\mathrm{~d}, 1)$ & $7.537(\mathrm{~d}, 2)$ & $7.533(\mathrm{~d}, 2)$ & $7.532(\mathrm{~d}, 2)$ & $7.520(\mathrm{~d}, 1)$ \\
\hline 5 & $3.018($ ddd, $2 / 6 / 8)$ & $3.086(\mathrm{dd}, 2 / 8)$ & $2.993(\mathrm{ddd}, 1 / 5 / 8)$ & $3.056(\mathrm{ddd}, 1 / 5 / 8)$ & 3.047 (ddd, $2 / 5 / 8)$ & \multicolumn{2}{|c|}{ ca. $3.02(\mathrm{~m})$} \\
\hline 6 & $4.794(\mathrm{~m})$ & a) & $4.544(\mathrm{dt}, 2 / 5)$ & $4.539(\mathrm{td}, 2 / 5)$ & $4.581(\mathrm{td}, 2 / 5)$ & \multicolumn{2}{|c|}{ ca. $4.58(\mathrm{~m})$} \\
\hline 7 & $6.019(\mathrm{~d}, 2)$ & $6.113(\mathrm{~d}, 2)$ & $5.081(\mathrm{t}, 2)$ & $5.925(\mathrm{~d}, 2)$ & $5.891(\mathrm{~d}, 2)$ & $5.867(\mathrm{~d}, 2)$ & $5.801(\mathrm{~d}, 2)$ \\
\hline 9 & $2.565(\mathrm{dd}, 7 / 8)$ & 2.724 (brt, 8 ) & $3.030(\mathrm{brt}, 7)$ & $3.149(\mathrm{brt}, 7)$ & $3.129(\mathrm{brt}, 8)$ & \multicolumn{2}{|c|}{$3.091(\mathrm{brt}, 7)$} \\
\hline $10 \mathrm{a}$ & $4.207(\mathrm{brd}, 15)$ & $5.023(\mathrm{brd}, 15)$ & 4.181 (brd, 15) & $5.011($ br d, 15) & $4.938(\mathrm{brd}, 15)$ & \multicolumn{2}{|c|}{ b) } \\
\hline $10 \mathrm{~b}$ & $4.453(\mathrm{dd}, 2 / 15)$ & $5.224(\mathrm{brd}, 15)$ & 4.336 (brd, 15) & 5.114 (br d, 15) & $5.071(\mathrm{brd}, 15)$ & \multicolumn{2}{|c|}{$4.978(\mathrm{brd}, 15)$} \\
\hline$-\mathrm{COOMe}$ & $3.741(\mathrm{~s})$ & $3.745(\mathrm{~s})$ & $3.751(\mathrm{~s})$ & $3.757(\mathrm{~s})$ & $3.754(\mathrm{~s})$ & $3.754(\mathrm{~s})$ & $3.750(\mathrm{~s})$ \\
\hline $1^{\prime}$ & $4.716(\mathrm{~d}, 8)$ & $4.749(\mathrm{~d}, 8)$ & $4.667(\mathrm{~d}, 8)$ & $4.699(\mathrm{~d}, 8)$ & $4.694(\mathrm{~d}, 8)$ & $4.697(\mathrm{~d}, 8)$ & $4.690(\mathrm{~d}, 8)$ \\
\hline $2^{\prime}$ & $3.239(\mathrm{dd}, 8 / 9)$ & $3.277(\mathrm{dd}, 8 / 9)$ & $3.205(\mathrm{dd}, 8 / 9)$ & $3.237(\mathrm{dd}, 8 / 9)$ & $3.234(\mathrm{dd}, 8 / 9)$ & \multicolumn{2}{|c|}{$3.240(\mathrm{dd}, 8 / 9)$} \\
\hline $3^{\prime}$ & a) & a) (रand & a) & a) & a) & \multirow{3}{*}{\multicolumn{2}{|c|}{$\begin{array}{c}\text { a) } \\
\text { ca. } 3.36\end{array}$}} \\
\hline $4^{\prime}$ & $3.389(\mathrm{t}, 9)$ & $3.392(\mathrm{t}, 9)$ & a) & $3.370(t, 9)$ & a) & & \\
\hline $5^{\prime}$ & a) & a) & a) & a) & a) & & \\
\hline $6^{\prime} \mathrm{a}$ & $3.617(\mathrm{dd}, 6 / 12)$ & $3.630(\mathrm{dd}, 6 / 12)$ & $3.633(\mathrm{dd}, 6 / 12)$ & $3.637(\mathrm{dd}, 6 / 12)$ & $3.639(\mathrm{dd}, 7 / 12)$ & \multicolumn{2}{|c|}{ ca. 3.64} \\
\hline $6^{\prime} \mathrm{b}$ & $3.847(\mathrm{dd}, 2 / 12)$ & $3.861(\mathrm{dd}, 2 / 12)$ & $3.863(\mathrm{dd}, 2 / 12)$ & $3.849(\mathrm{dd}, 2 / 12)$ & $3.852(\mathrm{dd}, 2 / 12)$ & \multicolumn{2}{|c|}{$3.869(\mathrm{brd}, 12)$} \\
\hline $2^{\prime \prime}, 6^{\prime \prime}$ & & $8.067(\mathrm{dd}, 1 / 8)$ & & $8.067(\mathrm{dd}, 1 / 8)$ & $7.919(\mathrm{~d}, 9)$ & $7.476(d, 9)$ & $7.636(d, 9)$ \\
\hline $3^{\prime \prime}, 5^{\prime \prime}$ & & $7.495(\mathrm{t}, 8)$ & & $7.496(t, 8)$ & $6.840(\mathrm{~d}, 9)$ & $6.810(\mathrm{~d}, 9)$ & $6.757(\mathrm{~d}, 9)$ \\
\hline $4^{\prime \prime}$ & & $7.621(\mathrm{tt}, 1 / 8)$ & & $7.622(\mathrm{tt}, 1 / 8)$ & & & \\
\hline $7^{\prime \prime}$ & & & & & & $7.663(\mathrm{~d}, 16)$ & $6.902(\mathrm{~d}, 13)$ \\
\hline $8^{\prime \prime}$ & & & & & & $6.378(\mathrm{~d}, 16)$ & $5.829(\mathrm{~d}, 13)$ \\
\hline
\end{tabular}

The letters and figures in parentheses are multiplicities and coupling constants in $\mathrm{Hz}$. a) Signals overlapped by the envelope of the solvent signal. b) Signal merged with the water signal.

spectrum closely resembled that of $\mathbf{4 a}$, except for the presence of additional four $s p^{2}$ signals, two of which were of double strength and a carboxyl carbon signal. Thus, compound 5 was expected to be an acylated derivative of 4a (Tables I and II). The acyl portion was actually composed of six aromatic signals and a carboxyl carbon signal, which is in accordance with those for benzoic acid. ${ }^{7)}$ Five aromatic proton signals, observed in the proton nuclear magnetic resonance $\left({ }^{1} \mathrm{H}-\mathrm{NMR}\right)$ spectrum, were coupled in the system, which also reflected that the acyl portion is benzoic acid. On acetylation of 5 in $\mathrm{Ac}_{2} \mathrm{O}$ and pyridine, pentaacetate was obtained, the ${ }^{1} \mathrm{H}-\mathrm{NMR}$ spectrum of which showed the presence of five alcoholic acetyl groups. The position of esterification was determined to be the 10-hydroxyl group of aglucone, since, when the ${ }^{13} \mathrm{C}-\mathrm{NMR}$ spectra of compounds $4 \mathbf{a}$ and 5 were compared, the $\mathrm{C}-10$ signal of $\mathbf{4 a}$ was found to be significantly shifted downfield, by $+2.6 \mathrm{ppm}$, on acylation, the $\beta$-position (C-8) shifted upfield by $-5.5 \mathrm{ppm}$, and the $\gamma$-position (C-7) downfield by +2.1 ppm (Table I). ${ }^{8)}$ This was also supported by the results of ${ }^{1} \mathrm{H}-\mathrm{NMR}$ spectroscopy, i.e., the two protons on $\mathrm{C}-10$ were shifted downfield, by about $0.8 \mathrm{ppm}$ on acylation (Table II). Therefore, the structure of compound $\mathbf{5}$ was concluded to be $10-O$-benzoyl-deacetyl asperulosidic acid methyl ester.

Compound $\mathbf{6}$ was obtained as an amorphous powder and determined to be scandoside methyl ester from the spectroscopic data. ${ }^{1)}$

Compound 7 was obtained as an amorphous powder. On HR-FAB-MS, its molecular composition was determined to be $\mathrm{C}_{24} \mathrm{H}_{28} \mathrm{O}_{12}$. On comparison of the spectroscopic data for compounds 6 and 7, compound 7 was expected to be an acylated derivative of $\mathbf{6}$, as in the case for compounds 4a and 5 . The acyl portion was also determined to be benzoic acid and from substitution shift trends, induced by acylation, the esterified position was concluded to be the
C-10 hydroxyl group of aglucone. Thus, the structure of compound 7 was consequently determined to be $10-O$ benzoyl scandoside methyl ester.

Compound 8, $\mathrm{C}_{24} \mathrm{H}_{28} \mathrm{O}_{13}$, was also obtained as an amorphous powder. The molecular composition determined by HR-FAB-MS indicated that this compound has one more oxygen atom than compound 7 . The chemical shifts in ${ }^{1} \mathrm{H}$ - and ${ }^{13} \mathrm{C}-\mathrm{NMR}$ spectra were essentially the same as those in the case of compound 6, except for in the acyl portion (Tables I and II). Of four aromatic carbon signals, two were of double strength, which indicated that the acyl portion included a para-substituted benzene system $(\delta 116.3$ and 133.0); one of the substituents was assumed to be a hydroxyl group, taking into account that the ${ }^{13} \mathrm{C}-\mathrm{NMR}$ signal appeared at $\delta 163.8 \mathrm{ppm}$. The observation of two aromatic proton signals coupled in an AA'BB' system $[\delta 6.840(\mathrm{~d}, J=9 \mathrm{~Hz})$ and $7.919(\mathrm{~d}, J=9 \mathrm{~Hz})]$ confirmed that the structure of the acyl moiety was $p$-hydroxybenzoic acid. ${ }^{9)}$ The position of esterification was also determined to be the C-10 hydroxyl group from the acylation induced shift trend, which was similar to previous cases. On acetylation with a mixture of $\mathrm{Ac}_{2} \mathrm{O}$ and pyridine, hexaacetate was obtained. The ${ }^{1} \mathrm{H}-\mathrm{NMR}$ spectrum indicated that there were five acetyl groups attached to alcoholic groups and one to a phenolic hydroxyl group. Therefore, compound 8 was determined to be $10-O-p$-hydroxybenzoyl scandoside methyl ester.

Compound 9 was obtained as an inseparable amorphous mixture; however, it showed a single spot on thin layer chromatogram $\left(\mathrm{CHCl}_{3}: \mathrm{MeOH}: \mathrm{H}_{2} \mathrm{O}=15: 6: 1\right.$ and EtOAc: $\left.\mathrm{EtOH}: \mathrm{H}_{2} \mathrm{O}=8: 2: 1\right)$ and one peak by HPLC. Its molecular composition was determined to be $\mathrm{C}_{26} \mathrm{H}_{30} \mathrm{O}_{13}$ by HR-FAB-MS. The ${ }^{1} \mathrm{H}$ - and ${ }^{13} \mathrm{C}-\mathrm{NMR}$ spectra indicated that compound 9 was also an acylated derivative of scandoside methyl ester. However, these NMR spectra showed some complexity. The ${ }^{13} \mathrm{C}-\mathrm{NMR}$ signals for 
aglucone and glucose moieties unexceptionally appeared with smaller satellite peaks. In the ${ }^{1} \mathrm{H}-\mathrm{NMR}$ spectrum, two sets of doublets at $\delta 6.378(\mathrm{~d}, J=16 \mathrm{~Hz})$ and $7.663(\mathrm{~d}$, $J=16 \mathrm{~Hz})$, and $\delta 5.829(\mathrm{~d}, J=13 \mathrm{~Hz})$ and $6.902(\mathrm{~d}, J=13 \mathrm{~Hz})$ indicated the existence of trans and cis double bonds, respectively. Aromatic proton signals were observed as doublets at $\delta 6.810(\mathrm{~d}, J=9 \mathrm{~Hz})$, and $7.476(\mathrm{~d}, J=9 \mathrm{~Hz})$, were accompanied by smaller similar signals at $\delta 6.757(\mathrm{~d}$, $J=9 \mathrm{~Hz})$ and $7.636(\mathrm{~d}, J=9 \mathrm{~Hz})$, which are assumed to be due to a cis isomer. This data implied the acyl portion is a para-substituted cinnamic acid, and the ${ }^{13} \mathrm{C}-\mathrm{NMR}$ data reported for the trans and cis-p-coumaric acids showed good agreement with those for the acyl moiety. ${ }^{10)}$ The trans and cis ratio was calculated to be approximately $70: 30$ from the proton signal integrals. The position of acylation was determined to be at the C-10 hydroxyl group, as in the cases of the compounds previously discussed, since between compounds 6 and 9, similar acylation-induced shift trends were observed at the $\mathrm{C}-10, \mathrm{C}-8$ and $\mathrm{C}-7$ positions. Thus, the structure of 9 was concluded to be $10-O-p$-coumaroyl scandoside methyl ester.

\section{Experimental}

Each melting point was determined with a Yanagimoto micro melting point apparatus and is uncorrected. ${ }^{1} \mathrm{H}$ - and ${ }^{13} \mathrm{C}$-NMR spectra were recorded on a JEOL GX-400 spectrometer at $400 \mathrm{MHz}$ and $100 \mathrm{MHz}$, respectively, and chemical shifts are given in ppm, with tetramethylsilane as an internal standard. Dioxane $\left(\delta_{\mathrm{C}}=67.4 \mathrm{ppm}\right)$ and $\operatorname{HDO}\left(\delta_{\mathrm{H}}=4.70 \mathrm{ppm}\right)$ were used as internal standards for ${ }^{13} \mathrm{C}$ - and ${ }^{1} \mathrm{H}$-NMR in $\mathrm{D}_{2} \mathrm{O}$, respectively. IR and UV spectra were obtained with Shimadzu IR-408 and UV-200S spectrophotometers, respectively. Optical rotations were measured with a Union Giken PM-101 automatic digital polarimeter. Mass spectra were recorded on a JEOL SX-102 mass spectrometer under the following conditions: electron impact (EI)-MS, $70 \mathrm{eV}$; FAB-MS, glycerol as a matrix for non-acetates, and $m$-nitrobenzyl alcohol for acetates. DCCC separation was carried out by an ascending method with $\mathrm{CHCl}_{3}-\mathrm{MeOH}-\mathrm{H}_{2} \mathrm{O}-$ $n$-PrOH $(9: 12: 8: 2)$ as a solvent system and with 500 columns $(2 \mathrm{~mm} \times 40 \mathrm{~cm})$. Four gram fractions were obtained and numbered according their elution with the mobile phase.

Isolation Procedure The plant material $(460 \mathrm{~g})$ was extracted with $n$-hexane three times under reflux to give $7.0 \mathrm{~g}$ of a hexane extract. The residue was extracted four times with $\mathrm{MeOH}$ for $3 \mathrm{~h}$ under reflux. The $\mathrm{MeOH}$ extract $(42 \mathrm{~g})$ was dissolved in $95 \%$ aq. $\mathrm{MeOH}$ and then extracted with $n$-hexane. The $\mathrm{MeOH}$ layer was concentrated to dryness to give $40 \mathrm{~g}$ of a brown mass. This was separated by a highly porous synthetic resin, Diaion HP-20, with the solvent system of $20 \%, 40 \%, 60 \%(\mathrm{a}, \mathrm{b})$ and $80 \%$ $(\mathrm{a}, \mathrm{b}, \mathrm{c}) \mathrm{MeOH}$ in water, and then with $\mathrm{MeOH}$.

The $20 \% \mathrm{MeOH}$ fraction (1.48 g) was again subjected to Diaion HP-20 column chromatography with a $5 \%$ stepwise increase in the $\mathrm{MeOH}$ content from $100 \% \mathrm{H}_{2} \mathrm{O}$, which gave $711 \mathrm{mg}$ of a compound 4-rich fraction in the $5 \% \mathrm{MeOH}$ eluate. After checking by ${ }^{1} \mathrm{H}-\mathrm{NMR}$ that the compounds in this fraction did not have any methoxyl groups, the $\mathrm{MeOH}$ solution of the fraction $(364 \mathrm{mg})$ was treated with ethereal diazomethane and then purified by DCCC (frs. 33-42) to give $169 \mathrm{mg}$ of compound 4a. An aliquot $(317 \mathrm{mg}$ ) of the $40 \% \mathrm{MeOH}$ fraction $(645 \mathrm{mg}$ ) was subjected to DCCC to . give $115 \mathrm{mg}$ of compound 1 (frs. 26-35). Purification of the $60 \%$ (a) $\mathrm{MeOH}$ eluate $(0.69 \mathrm{~g})$ by silica gel column chromatography $\left(\mathrm{CHCl}_{3}\right.$ $\mathrm{MeOH}, 9: 1$ ) afforded $212 \mathrm{mg}$ of compound 6 . A portion (511 $\mathrm{mg}$ ) of the $\mathrm{b}$ fraction of the $60 \% \mathrm{MeOH}$ eluate $(1.18 \mathrm{~g})$ was first separated by two runs of DCCC to give $140 \mathrm{mg}$ of a compound 2-rich (frs. 68-88) fraction and $289 \mathrm{mg}$ of a compound 3-rich (frs. 36-48) fraction. Compound 2 $(39 \mathrm{mg})$ was obtained as colourless needles by recrystallization of the fraction from $\mathrm{H}_{2} \mathrm{O}$. Compound $3(87 \mathrm{mg})$ was isolated by silica gel column chromatography $\left(\mathrm{CHCl}_{3}-\mathrm{MeOH}-\mathrm{H}_{2} \mathrm{O}, 30: 12: 1\right)$ from the compound 3-rich fraction. The $\mathrm{b}$ fraction of the $80 \% \mathrm{MeOH}$ eluate $(2.25 \mathrm{~g})$ gave compound $8(15 \mathrm{mg})$, after separation by both silica gel column chromatography $\left(\mathrm{CHCl}_{3}-\mathrm{MeOH}-\mathrm{H}_{2} \mathrm{O}, 150: 30: 1\right)$ and preparative HPLC (TSK gel, octadecyl silica (ODS), $50 \% \mathrm{MeOH})$. The c fraction $(2.27 \mathrm{~g})$ of the $80 \%$. MeOH eluate was subjected to silica gel column chromatography. The second fraction $(305 \mathrm{mg})$, eluted with $\mathrm{CHCl}_{3}-$
$\mathrm{MeOH}-\mathrm{H}_{2} \mathrm{O}$ (150:30:1), was further separated by silica gel column chromatography $\left(\mathrm{CHCl}_{3}-\mathrm{MeOH}, 96: 4\right)$ and preparative HPLC (TSK gel, ODS, $60 \% \mathrm{MeOH}$ ) to give $24 \mathrm{mg}$ of compound 7. Compounds 5 and 9 were isolated from the third fraction $(441 \mathrm{mg})$, with elution with $\mathrm{CHCl}_{3}-\mathrm{MeOH}-\mathrm{H}_{2} \mathrm{O}(150: 30: 1)$. Further column chromatography on silica gel $\left(\mathrm{CHCl}_{3}-\mathrm{MeOH}, 96: 4\right)$ of the fraction led to the condensation of compounds 5 and $9(155 \mathrm{mg})$. Finally, preparative HPLC with $65 \%$ $\mathrm{MeOH}$ afforded $40 \mathrm{mg}$ of compound 9 from the slower-eluted portion, and $22 \mathrm{mg}$ of compound $\mathbf{5}$ was isolated by repeated preparative HPLC of the faster-eluted portion $(60 \% \mathrm{MeOH})$ with $45 \% \mathrm{MeOH}$. Analytical HPLC of 9 was performed on an Inertsil ODS column $(6 \times 250 \mathrm{~mm}, 45 \%$ aq $\mathrm{MeOH}$, at $22^{\circ} \mathrm{C}, 1.5 \mathrm{ml} / \mathrm{min}$; detection: $\mathrm{UV}$ at $\left.310 \mathrm{~nm}\right)$. The $t_{\mathrm{R}}(\mathrm{min})$ of compound 9 was 17.3 (a single peak).

Known Compounds Isolated Deacetyl asperuloside (1), an amorphous powder. $[\alpha]_{\mathrm{D}}^{22}-140.0^{\circ}(c=0.75, \mathrm{MeOH})$. FAB-MS $m / z: 373\left([\mathrm{MH}]^{+}\right)$, $395\left([\mathrm{M}+\mathrm{Na}]^{+}\right)(+\mathrm{NaI}), 411\left([\mathrm{M}+\mathrm{K}]^{+}\right)(+\mathrm{KI}) \cdot{ }^{13} \mathrm{C}-\mathrm{NMR}\left(\mathrm{CD}_{3} \mathrm{OD}\right)$ $\delta: 37.5(\mathrm{~d}, \mathrm{C}-5), 45.0(\mathrm{~d}, \mathrm{C}-9), 60.1(\mathrm{t}, \mathrm{C}-10), 62.8\left(\mathrm{t}, \mathrm{C}-6^{\prime}\right), 71.6\left(\mathrm{~d}, \mathrm{C}-4^{\prime}\right)$, 74.7 (d, C-2'), 77.9 (d, C-5'), 78.4 (d, C-3'), 86.7 (d, C-6), 93,4 (d, C-1), 99.9 (d, C-1'), 106.5 (s, C-4), 125.8 (d, C-7), 149.8 (s, C-8), 150.3 (d, C-3), 172.9 (s, C-11). The spectroscopic data for the pentaacetate of deacetyl asperuloside were indistinguishable from those for the tetraacetate of asperuloside.

Asperuloside (2): Colorless needles $\left(\mathrm{H}_{2} \mathrm{O}\right), \mathrm{mp} 124-126^{\circ} \mathrm{C}$, lit. ${ }^{1)}$ $120-123^{\circ} \mathrm{C} . \quad[\alpha]_{\mathrm{D}}^{22}-190.0^{\circ}(c=1.60, \mathrm{MeOH}) . \quad$ FAB-MS $m / z: 415$ $\left([\mathrm{MH}]^{+}\right), 437\left([\mathrm{M}+\mathrm{Na}]^{+}\right)(+\mathrm{NaI}), 453\left([\mathrm{M}+\mathrm{K}]^{+}\right)(+\mathrm{KI}) ;{ }^{13} \mathrm{C}-\mathrm{NMR}$ $\left(\mathrm{CD}_{3} \mathrm{OD}\right) \delta: 20.7$ (q, $\left.\mathrm{CH}_{3} \mathrm{CO}-\right), 37.5$ (d, C-5), $45.2(\mathrm{~d}, \mathrm{C}-9), 60.9(\mathrm{t}, \mathrm{C}-10)$, 62.8 (t, C-6'), 71.5 (d, C-4'), 74.6 (d, C-2'), 77.8 (d, C-5'), 78.3 (d, C-3'), 86.3 (d, C-6), 93.3 (d, C-1), 100.0 (d, C-1'), 106.2 (s, C-4), 128.9 (d, C-7), 144.2 (s, C-8), 150.3 (d, C-3), 172.2, 172.5 (both s, C-11 and $\mathrm{CH}_{3} \mathrm{CO}-$ ). ${ }^{13} \mathrm{C}-\mathrm{NMR}\left(\mathrm{D}_{2} \mathrm{O}\right) \delta: 21.0,36.7,44.4,61.6,62.3,70.4,73.4,76.3,77.2,87.1$, 93.7, 99.4, 105.5, 128.9, 143.0, 150.7, 174.2, 174.5. ${ }^{11}$

Asperulosidic Acid (3): An amorphous powder. $[\alpha]_{D}^{23}+21.7^{\circ}(c=0.69$, $\mathrm{MeOH})$. FAB-MS $m / z: 455\left([\mathrm{M}+\mathrm{Na}]^{+}\right)(+\mathrm{NaI}), 471\left([\mathrm{M}+\mathrm{K}]^{+}\right)(+\mathrm{KI})$. ${ }^{13} \mathrm{C}-\mathrm{NMR}\left(\mathrm{CD}_{3} \mathrm{OD}\right) \delta: 20.8\left(\mathrm{q}, \mathrm{CH}_{3} \mathrm{CO}-\right), 42.6(\mathrm{~d}, \mathrm{C}-5), 46.3$ (d, C-9), 63.0 (t, C-6'), 63.8 (t, C-10), 71.5 (d, C-4'), 74.9 (d, C-2'), 75.4 (d, C-6), 77.8 (d, C-5'), 78.5 (d, C-3'), 100.5 (d, C-1'), 101.2 (d, C-1), 131.9 (d, C-7), 145.9 (s, C-8), 155.0 (d, C-3), 171.2, 172.5 (both s, $\mathrm{C}-11$ and $\mathrm{CH}_{3} \mathrm{CO}-$ ). ${ }^{12)}$ The signal for $\mathrm{C}-4$ at around $110 \mathrm{ppm}$ was missing, maybe due to formation of the carboxylate anion. ${ }^{13)}$

Deacetyl Asperulosidic Acid (4): Characterized as its methyl ester (deacetyl asperulosidic acid methyl ester) (4a). An amorphous powder, $[\alpha]_{\mathrm{D}}^{23}+22.6^{\circ}(c=1.33, \mathrm{MeOH})$, FAB-MS $m / z: 427\left([\mathrm{M}+\mathrm{Na}]^{+}\right)(+\mathrm{NaI})$, $443\left([\mathrm{M}+\mathrm{K}]^{+}\right)(+\mathrm{KI}) .{ }^{13} \mathrm{C}-\mathrm{NMR}\left(\mathrm{CD}_{3} \mathrm{OD}\right)$ : see Table I. ${ }^{1} \mathrm{H}-\mathrm{NMR}\left(\mathrm{D}_{2} \mathrm{O}\right)$ $\delta: 2.61(\mathrm{H}$, br t $, J=8.3 \mathrm{~Hz}, 9-\mathrm{H}), 3.08(\mathrm{H}, \mathrm{H}$, br t $, J=6.8 \mathrm{~Hz}, 5-\mathrm{H}), 3.32$ $\left(\mathrm{H}, \mathrm{dd}, J=8.0,9.2 \mathrm{~Hz}, 2^{\prime}-\mathrm{H}\right), 3.55\left(\mathrm{H}, \mathrm{t}, J=9.2 \mathrm{~Hz}, 3^{\prime}-\mathrm{H}\right), 3.46(\mathrm{H}, \mathrm{t}$, $\left.J=9.2 \mathrm{~Hz}, 4^{\prime}-\mathrm{H}\right), 3.64\left(\mathrm{H}, \mathrm{dd}, J=5.1,12.1 \mathrm{~Hz}, 6^{\prime}-\mathrm{H}_{\mathrm{a}}\right), 3.71(3 \mathrm{H}, \mathrm{s}), 3.82$ $\left(\mathrm{H}, \mathrm{dd}, J=1.5,12.1 \mathrm{~Hz}, 6^{\prime}-\mathrm{H}_{\mathrm{b}}\right), 4.22\left(\mathrm{H}, \mathrm{brd}, J=15.7 \mathrm{~Hz}, 10-\mathrm{H}_{\mathrm{a}}\right), 4.40(\mathrm{H}$, dd, $\left.J=1.3,15.7 \mathrm{~Hz}, 10-\mathrm{H}_{\mathrm{b}}\right), 4.79\left(\mathrm{H}, \mathrm{d}, J=8.0 \mathrm{~Hz}, 1^{\prime}-\mathrm{H}\right), 4.81(\mathrm{H}, \mathrm{brdd}-\mathrm{like}$, 6-H), $4.93(\mathrm{H}, \mathrm{d}, J=9.0 \mathrm{~Hz}, 1-\mathrm{H}), 5.99(\mathrm{H}, \mathrm{d}, J=1.8 \mathrm{~Hz}, 7-\mathrm{H}), 7.66(\mathrm{H}$, d, $J=1.3 \mathrm{~Hz}, 3-\mathrm{H}) .^{14)}$

Scandoside Methyl Ester (6): An amorphous powder, $[\alpha]_{\mathrm{D}}^{23}-34.8^{\circ}$ $(c=0.69, \mathrm{MeOH})$. FAB-MS $m / z: 427\left([\mathrm{M}+\mathrm{Na}]^{+}\right)(+\mathrm{NaI}), 443\left([\mathrm{M}+\mathrm{K}]^{+}\right)$ $(+\mathrm{KI}) .{ }^{13} \mathrm{C}-\mathrm{NMR}\left(\mathrm{CD}_{3} \mathrm{OD}\right)$ : see Table I. ${ }^{1} \mathrm{H}-\mathrm{NMR}\left(\mathrm{D}_{2} \mathrm{O}\right) \delta: 3.03(\mathrm{H}$, dd, $J=3.4,7.5 \mathrm{~Hz}, 5-\mathrm{H}), 3.16(\mathrm{H}$, br t $, J=5.5 \mathrm{~Hz}, 9-\mathrm{H}), 3.25(\mathrm{H}, \mathrm{dd}, J=8.3$, $\left.9.0 \mathrm{~Hz}, 2^{\prime}-\mathrm{H}\right), 3.33\left(\mathrm{H}, \mathrm{t}, J=9.0 \mathrm{~Hz}, 3^{\prime}-\mathrm{H}\right), 3.39(\mathrm{H}, \mathrm{ddd}, J=1.9,5.7,9.0 \mathrm{~Hz}$, $\left.5^{\prime}-\mathrm{H}\right), 3.44\left(\mathrm{H}, \mathrm{t}, J=9.0,4^{\prime}-\mathrm{H}\right), 3.65\left(\mathrm{H}, \mathrm{dd}, J=5.7,12.3,6^{\prime}-\mathrm{H}_{\mathrm{a}}\right), 3.71(3 \mathrm{H}$, s), $3.82\left(\mathrm{H}, \mathrm{dd}, J=1.9,12.3 \mathrm{~Hz}, 6^{\prime}-\mathrm{H}_{\mathrm{b}}\right), 4.20\left(\mathrm{H}, \mathrm{br} \mathrm{d}, J=15.2 \mathrm{~Hz}, 10-\mathrm{H}_{\mathrm{a}}\right)$, $4.28\left(\mathrm{H}, \mathrm{brd}, J=15.2 \mathrm{~Hz}, 10-\mathrm{H}_{\mathrm{b}}\right), 4.57(\mathrm{H}$, very brs, 6-H), $4.72(\mathrm{H}, \mathrm{d}$, $\left.J=8.3 \mathrm{~Hz}, \mathrm{l}^{\prime}-\mathrm{H}\right), 5.34(\mathrm{H}, \mathrm{d}, J=5.1 \mathrm{~Hz}, 1-\mathrm{H}), 5.78(\mathrm{H}, \mathrm{br} \mathrm{s}, 7-\mathrm{H}), 7.45(\mathrm{H}$, $\mathrm{s}, 3-\mathrm{H}){ }^{1,15)}$

10-O-Benzoyl Deacetyl Asperulosidic Acid Methyl Ester (5) An amorphous powder, $[\alpha]_{\mathrm{D}}^{22}+21.4^{\circ}(c=1.40, \mathrm{MeOH})$. IR $v_{\max }^{\mathrm{KB}} \mathrm{cm}^{-1}: 3420$, $2925,1710,1635,1445,1315,1275,1150,1100,1075,1045,780,715$. UV $\lambda_{\max }^{\mathrm{MeOH}} \mathrm{nm}(\log \varepsilon): 211$ (3.65) inf, 231 (4.21). HR-FAB-MS $m / z: 531.1494$ $\left([\mathrm{M}+\mathrm{Na}]^{+}\right) \quad(+\mathrm{NaI}) \quad\left(\mathrm{C}_{24} \mathrm{H}_{28} \mathrm{O}_{12} \mathrm{Na}\right.$ requires 531.1478). ${ }^{1} \mathrm{H}-$ and ${ }^{13} \mathrm{C}$-NMR: see Tables I and II.

10-O-Benzoyl Scandoside Methyl Ester (7) An amorphous powder, $[\alpha]_{\mathrm{D}}^{22}-22.5^{\circ}(c=0.71, \mathrm{MeOH})$. IR $v_{\max }^{\mathrm{KBr}} \mathrm{cm}^{-1}: 3375,2875,1705,1630$, $1440,1380,1310,1275,1155,1110,1070,805,770,715$. UV $\lambda_{\max }^{\text {MeOH }} \mathrm{nm}(\log$ 8): 213 (3.60) inf, 232 (4.26). HR-FAB-MS $m / z: 531.1503\left([\mathrm{M}+\mathrm{Na}]^{+}\right)$ $(+\mathrm{NaI})\left(\mathrm{C}_{24} \mathrm{H}_{28} \mathrm{O}_{12} \mathrm{Na}\right.$ requires 531.1478). ${ }^{1} \mathrm{H}$ - and ${ }^{13} \mathrm{C}-\mathrm{NMR}$ : see Tables I and II.

10-O-p-Hydroxybenzoyl Scandoside Methyl Ester (8) An amorphous powder, $[\alpha]_{\mathrm{D}}^{22}-17.0^{\circ}(c=1.00, \mathrm{MeOH})$. IR $v_{\max }^{\mathrm{KBr}} \mathrm{cm}^{-1}: 3420,2955,1700$, $1630,1605,1515,1440,1385,1310,1275,1165,1100,1080,895,850,770$. 
UV $\lambda_{\max }^{\mathrm{MeOH}} \mathrm{nm}(\log \varepsilon): 213$ (3.94), 251 (4.11). HR-FAB-MS $m / z: 547.1497$ $\left([\mathrm{M}+\mathrm{Na}]^{+}\right) \quad(+\mathrm{NaI})\left(\mathrm{C}_{24} \mathrm{H}_{28} \mathrm{O}_{13} \mathrm{Na}\right.$ requires 547.1427$) .{ }^{1} \mathrm{H}-$ and ${ }^{13} \mathrm{C}-\mathrm{NMR}$ : see Tables I and II.

10-O-p-trans, cis-Coumaroyl Scandoside Methyl Ester (9) An amorphous powder, $[\alpha]_{\mathrm{D}}^{22}-20.0^{\circ}(c=1.35, \mathrm{MeOH}) . \mathrm{IR} v_{\max }^{\mathrm{KBr}} \mathrm{cm}^{-1}: 3425,2920$, $1700,1635,1605,1515,1440,1385,1310,1280,1170,1100,1080,955$ $890,840,770$. UV $\lambda_{\max }^{\mathrm{MeOH}} \mathrm{nm}(\log \varepsilon): 215(4.03), 230(4.15), 302(4.10), 313$ (4.15). HR-FAB-MS $m / z: 573.1557\left([\mathrm{M}+\mathrm{Na}]^{+}\right)(+\mathrm{NaI})\left(\mathrm{C}_{26} \mathrm{H}_{30} \mathrm{O}_{13} \mathrm{Na}\right.$ requires 573.1584). ${ }^{1} \mathrm{H}$ - and ${ }^{13} \mathrm{C}$-NMR: see Tables I and II.

Acetates of Compounds 5, 7, 8 and 9 Compounds 5, 7,8 and 9 (about $3 \mathrm{mg}$ each) were acetylated with a mixture of $\mathrm{Ac}_{2} \mathrm{O}$ ( 3 drops) and pyridine ( 3 drops) at $25^{\circ} \mathrm{C}$ overnight. Each reaction solution was evaporated to dryness. Compound 5 pentaacetate. FAB-MS $m / z$ : $741\left([\mathrm{M}+\mathrm{Na}]^{+}\right), 169$ $(+\mathrm{NaI}), 757\left([\mathrm{M}+\mathrm{K}]^{+}\right)(+\mathrm{KI})$. EI-MS $m / z$ (rel. int.): $718\left([\mathrm{M}]^{+}\right)(<1)$ $368(14), 331\left(\left[\text { Gluc }(\text { Ac) }]_{4}\right]^{+}\right)(87), 169$ (100), 133 (50), 109 (44). ${ }^{1}$ H-NMR $\left(\mathrm{CDCl}_{3}\right) \delta: 1.95,2.02(\times 2), 2.09,2.03$. Compound 7 pentaacetate. FAB-MS $m / z: 741\left([\mathrm{M}+\mathrm{Na}]^{+}\right), 169(+\mathrm{NaI}), 757\left([\mathrm{M}+\mathrm{K}]^{+}\right)(+\mathrm{KI})$. EI-MS $m / z$ (rel. int.): 368 (19), 331 ([Gluc(AC) $]_{4}^{+}$) (65), 169 (100), 133 (67), 108 (48). ${ }^{1} \mathrm{H}-\mathrm{NMR}\left(\mathrm{CDCl}_{3}\right) \delta: 1.95,2.006,2.010,2.02,2.06$ Compound 8 hexaacetate. FAB-MS $m / z: 799\left([\mathrm{M}+\mathrm{Na}]^{+}\right), 172,169$ $(+\mathrm{NaI}), 815\left([\mathrm{M}+\mathrm{K}]^{+}\right)(+\mathrm{KI})$. EI-MS $m / z$ (rel. int.): 538 (4), 331 ([Gluc $\left.\left.(\mathrm{Ac})_{4}\right]^{+}\right)(65), 169(100), 109(42) .{ }^{1} \mathrm{H}-\mathrm{NMR}\left(\mathrm{CDCl}_{3}\right) \delta: 1.94,2.01,2.02$, $2.03,2.07,2.32$. Compound 9 hexaacetate. FAB-MS $m / z: 825\left([\mathrm{M}+\mathrm{Na}]^{+}\right)$ $(+\mathrm{NaI}), 841\left([\mathrm{M}+\mathrm{K}]^{+}\right)(+\mathrm{KI})$. EI-MS $m / z$ (rel. int.): $386(12), 368$ (22), $331\left(\left[\text { Gluc }(\mathrm{Ac})_{4}\right]^{+}\right)(59), 169(100), 157(48), 133$ (39), $109(52) .{ }^{1}$ H-NMR $\left(\mathrm{CDCl}_{3}\right) \delta: 1.955(E), 2.006(E+Z), 2.027(E+Z), 2.059(E), 2.062(Z)$ $2.068(Z), 2.098(E+Z), 2.302(Z), 2.314(E)$.

Acknowledgment This study was supported by a Research Study Grant under the JSPS International Joint Research Project.

\section{References}

1) S. Takagi, M. Yamaki, K. Masuda, Y. Nishihama, and K. Sakina, Yakugaku Zasshi, 101, 657 (1981).

2) Y. Nishihama, K. Masuda, M. Yamaki, S. Takagi, and K. Sakina, Planta Med., 43, 28 (1981).

3) A. Rimando, S. Inoshiri, H. Otsuka, H. Kohda, K. Yamasaki, W. G. Padolina, L. Torres, E. G. Quintana, and M. C. Cantoria, Jpn. J. Pharmacog., 41, 242 (1987).

4) H. Otsuka, N. Kubo, K. Yamasaki, and W. G. Padolina, Phytochemistry, 28, 3065 (1989).

5) A. Quisumbing, "Medicinal Plants of the Philippines," Katha Publishing Co., Quezon City, 1978, pp. 920-921.

6) C. A. Boros and F. R. Stermitz, J. Nat. Prod., 53, 1055 (1990).

7) R. K. Chaudhuri and O. Sticher, Helv. Chim. Acta, 63, 117 (1980).

8) V. M. Chari, M. Jordan, H. Wagner, and P. W. Thies, Phytochemistry, 16, 1110 (1977).

9) S. F. El-Naggar and R. W.Doskotch, J. Nat. Prod., 43, 524 (1980).

10) J. Garcia and A. J. Chulia, Planta Med., 1986, 101.

11) F. Bailleul, P. Delaveau, A. Rabaron, M. Plat, and M. Koch, Phytochemistry, 16, 723 (1977).

12) R. K. Chaudhuri, F. U. Afifi-Yazar, O. Sticher, and T. Winkler, Tetrahedron, 36, 2317 (1980).

13) G. König, H. Rimpler, and D. Hunkler, Phytochemistry, 26, 423 (1987).

14) A. Bianco, M. Guiso, C. Iavarone, P. Passacantilli, and C. Trogolo, Gazz. Chim. Ital., 108, 13 (1978).

15) H. Inouye, Y. Takeda, and H. Nishimura, Phytochemistry, 13, 2219 (1974). 